\title{
KONSEP DASAR DALAM SISTEM KEUANGAN SYARIAH
}

\author{
Rahmat Ilyas \\ STAIN Syaikh Abdurrahman Siddik Bangka Belitung
}

\begin{abstract}
Dinul Islam is a comprehensive living system that Allah swt down through His Apostle. Which includes aqidah, ubudiah, mu'amalah, mu'asyarah and morals that guide people so life is full of glory. Comprehensive concept means comprehensive rules that encompass various aspects of life, whether of dimension of belief (aqidah), ritual of self-servant (ubudiah), and social aspect ie mu'amalah, mu'asyarah and morals. In everyday life, economy is the wheel of life as a container to meet the material needs of human beings, both in individual life, and social. Islam leads its people to embrace and practice Islamic teachings in a kaffah (comprehensive / comprehensive) in all aspects of life.
\end{abstract}

Keywords: Islam, Komprehenshif, Kaffah

\section{A. Pendahuluan}

Dinul Islam adalah suatu sistem hidup komprehensif yang Allah swt turunkan melalui Rasul-Nya.yang meliputi aqidah, ubudiah, mu'amalah, mu'asyarah dan akhlak yang memandu manusia sehingga hidup penuh kemuliaan. Konsep komprehensif bermakna aturan menyeluruh yang merangkum berbagai aspek kehidupan, baik berdimensi keyakinan (aqidah), ritualitas penghambaan diri (ubudiah), dan aspek sosial yaitu mu'amalah, mu'asyarah dan akhlak. ${ }^{1}$

Ajaran Islam tentang perekonomian, akan senantiasa menarik untuk dibahas. Dalam kehidupan sehari-hari, ekonomi merupakan roda kehidupan sebagai wadah untuk memenuhi kebutuhan materiil manusia, baik dalam kehidupan individu, maupun sosial. Islam menuntun umatnya untuk

\footnotetext{
${ }^{1}$ Lukman Hakim, Prinsip-prinsip Ekonomi Islam, (Jakarta, Erlangga, 2012), hlm. 2
} 
Rahmat Ilyas

menganut dan mengamalkan ajaran Islam secara kaffah (menyeluruh/komprehensif) dalam seluruh aspek kehidupan. Sebagai seorang muslim yang taat beribadah, tentulah berbagai kegiatan bisnis atau usahanya dilandasi oleh transaksi keuangan Islami.

Belakangan ini aktivitas ekonomi dan keuangan syariah telah memasuki tahapan perkembangan secra signifikan, sehingga kajian terhadap konsep dan teori keuangan syariah mencuat pula.

Pada umumnya perkembangan teori keuangan banyak didasarkan pada pengamatan terhadap fenomena yang dihadapi oleh pasar keuangan dan perusahan. Hal ini tidak berarti bahwa konsep dan teori keuangan tersebut tidak dapat diterapkan pada lembaga individu maupun pemerintah. Penerapan teori keuangan dalam lingkup perusahaan sering diset dengan keuangan perusahaan atau juga dikenal dengan manajemen keuangan. Dengan demikian jika perusahaan tersebut beroperasi dengan prinsip-prinsip syariah, maka akan muncul konsep keuangan syariah. Keuangan perusahaan syariah atau menajemen keuangan syariah dilakukan untuk mewujudkan atau memilih keputusan keuangan yang tepat bagi individu maupun perusahaan.

\section{B. Pengertian sistem keuangan Syariah}

Aktivitas suatu perusahaan sangat ditunjang oleh modal atau dana yang dimiliki oleh para pendirinya. Dana tersebut digunakan untuk membelanjai aktivitas-aktivitasnya. Dalam hubungan ini, maka perusahaan akan menghadapi penentuan metode yang tepat untuk menggunakan dana secara optimal. Dana perusahaan dapat diperoleh dari berbagai sumber, diantaranya dari pendiri, pasar uang, maupun pasar modal. Dalam kaitannya dengan manajemen keuangan, teori umumnya selalu berbicara mengenai, cara perusahaan mendapatkan dana dari pasar modal.

Kegiatan dalam manajemen keuangan mencakup kegiatan perencanaan keuangan, analisis keuanga dan pengendalian keuangan. Orang melaksanakan 
kegiatan manajemen keuangan disebut sebagai manajer keuangan. Seorang manajer keuangan dituntut untuk memiliki pengetahuan dan keterampilan mengenai securities and invesment analysis (analisis bisnis, investasi dan suratsurat berharga).

Manajemen keuangan syariah bisa diartikan sebagai manajemen terhadap fungsi-fungsi keuangan dengan bingkai syariah Islam yang berkaitan dengan masalah keuangan perusahaan. Secara garis besar, fungsi-fungsi perusahaan bisa dikelompokkan ke dalam empat fungsi, yaitu; (1) fungsi pemasaran, (2) fungsi keuangan; (3) fungsi produksi; (4) fungsi personalia. Keempat fungsi tersebut merupakan fungsi pokok suatu perusahaan. Fungsifungsi manajemen bisa dipecah kedalam beberapa hal; perencanaan (planning); pengorganisasian (organizing); staffing; pelaksanaan; dan pengendalian. ${ }^{2}$

Dengan demikian, manajemen keuangan syariah dapat diartikan sebagai kegiatan perencanaan, pengorganisasian, staffing, pelaksanaan, dan pengendalian fungsi-fungsi keuangan yang dituntun oleh prinsip-prinsip syariah.

\section{Konsep Islam Terhadap Bunga}

Praktik sistem keuangan syariah telah dilakukan sejak zaman kejayaan Islam. Namun seiring melemahnya sistem khalifa. Pada akhir abad ke-19, dinasti onttoman memperkenalkan sistem perbankan barat pada dunia Islam. Perkembangan selanjutnya pada akhir 1970-an mulailah berdiri bank yang mengadopsi sistem syariah kemudian berkembang pesat dan saat ini banyak negara telah melakukan kegiatan perdagangan dan bisnis.

Prinsip hukum Islam, yang berdasarkan pada sejumlah surah dalam al qur'an, menyatakan bahwa perbuatan memperkaya diri dengan cara yang tidak benar, atau menerima keuntungan tanpa memberikan nilai imbalan,

2 Muhammad, Manajemen Keuangan Syariah; analisis Fiqh \& Keuangan, (Yogyakarta:UPP STIM YKPN, 2014), hlm. 2 
secara etika dilarang. Menurut Schacht riba hanyalah sebuah kasus khusus dari perbuatan memperkaya diri secara tidak benar atau menurut al qur'an memakan (yaitu mengambil untuk kepentingan diri sendiri) milik orang lain dengan alasan yang tidak dibenarkan dan dilarang. Riba secara formal didefenisikan sebagai suatu keuntungan moneter tanpa ada nilai imbalan yang ditetapkan untuk salah satu dari dua pihak yang mengatakan kontrak dalam pertukaran dua nilai moneter. ${ }^{3}$

Makna harfiah dari kata Arab riba adalah pertambahan, kelebihan, pertumbuhan atau peningkatan. Said mengtakan bahwa akar $r-b-w$ dalam al qur'an memiliki pengertian tumbuh, bertambah, naik, bengkak, meningkat, dan menjadi besar dan tinggi. Kata riba juga digunakan dalam pengertian bukit kecil. Semua penggunaan ini nampak memiliki satu makna yang sama, yakni pertambahan, baik secara kualitas maupun kuantitas. ${ }^{4}$

Filosofi sistem keuangan "bebas bunga" (larangan riba) tidak hanya melihat interaksi antara faktor produksi dan prilaku ekonomi seperti yang dikenal pada sistem keuangan konvensional, melainkan juga harus menyeimbankan berbagai unsur etika, moral, sosial dan dimensi keagamaan untuk meningkatkan pemerataan dan keadilan menuju masyarakat yang sejahtera secara menyeluruh. Melalui sistem kerjasama bagi hasil maka akan ada pembagian resiko. Resiko yang timbul dalam aktivitas keuangan tidak hanya di tanggung penerima modal atau pengusaha saja, namun juga resiko diterima oleh pemberi modal.

Riba merupakan pelanggaran atas sistem keadilan sosial, persamaan dan hak atas barang. Oleh karena sistem riba hanya menguntungkan para pemberi pinjaman / pemilik harta, sedangkan pengusaha tidak di perlakukan sama.

\footnotetext{
${ }^{3}$ Mervyn K \& Latifa M. Algaoud, Perbankan Syariah: Prinsip, Praktik dan Prospek, (Jakarta: PT. Serambil Ilmu Semesta, 2001), hlm. 55

${ }^{4}$ Ibid, 56
} 
Padahal untung itu baru diketahui setelah berlakunya waktu bukan hasil penetapan dimuka.

Imam ar-Razi mencoba menjelaskan alasan pelaranga riba karena empat hal: pertama, karena riba berarti mengambil harta sipeminjam secara tidak adil. Pemilik uang biasanya berdalih ia berhak atas keuntungan bisnis yang dilakukan sipeminjam. Namun, ia tampaknya lupa bila ia tidak meminjamkan, uangnya tidak bertambah. Kedua, dengan riba seseorang akan malas bekerja dan berbisnis karena dapat duduk-duduk tenang sambil menunggu uangnya berbunga. Imam razi mengatakan bahwa kegiatan produksi dan perdagangan aka lesu. Ketiga, riba akan merendahkan martabat manusia karena untuk memenuhi hasrat dunianya seseorang tidak segan-segan meminjam dengan bunga tinggi walau akhirnya dikejar-kejar penagih hutang. Keempat, riba akan membuat yang kaya bertambah kaya dan yang miskin bertambah miskin. Dalam masa kritis saat ini, orang kaya malah bertambah kaya karena bunga deposito dan simpanan. Kelima riba jelas-jelas dilarang oleh al-qur'an dan sunnah. ${ }^{5}$

\section{Gharar dalam Lembaga Keuangan Syariah}

Jual beli gharar adalah jual beli yang mengandung unsur-unsur penipuan, baik karena ketidakjelasan dalam objek jual beli atau ketidakpastian dalam cara pelaksanaannya. Hukum jual beli ini adalah haram. Alasan haramnya adalah tidak pasti dalam objek, baik barang atau uang atau cara transaksinya itu sendiri. Karena larangan dalam hal ini langsung menyentuh esensi jual belinya, maka disamping haram hukumnya transaksi itu tidak sah. ${ }^{6}$

Larangan Melakukan Kegiatan Spekulatif. Hal ini sama dengan pelanggaran untuk transaksi yang memiliki tingkat ketidakpastian yang sangat

\footnotetext{
5 Adiwarman A karim, Ekonomi Islam Suatu Kajian Kontemporer, (Jakarta: Gema Insani Press, 2001), hlm. 71

6 Amir Syarifuddin, Garis-garis Besar Fiqh, (Jakarta: Kencana, 2010), hlm. 201
} 
Rahmat Ilyas

tinggi, judi dan transaksi yang memiliki resiko yang sangat besar. Kesucian Kontrak. Oleh karena itu islm menilai perjanjian sebagai suatu yang tinggi nilainya sehingga seluruh kewajiban dan pengungkapan yang terkait dengan kontrak harus dilakukan. Hal ini akan mengurangi resiko atas informasi yang asimetri dan timbulnya moralhazard.

Aktifitas usaha harus sesuai Syariah. Seluruh kegiatan usaha tersebut haruslah merupakan kegiatan yang diperbolehkan menurut syariah. Jadi, prinsip keuangan syariah mengacuh pada prinsip rela sama rela (antaraddim minkum) tidak ada pihak disalimi dan mensalimi (la tazhlimuna wa la tuzhlamun), hasil biaya muncul bersama biaya, dan untung muncul bersama resiko.

Larangan jual beli gharar merupakan kaidah besar ilmu perdagangan Islam. Banyak permasalahan besar yang tidak bisa dihitung dengan jari yang tercakup di dalamnya. Seperti menjual barang yang tidak ada, atau tidak diketahui keberadaannya, atau tidak bisa diserahterimakan, atau barang yang belum sempurna menjadi milik penjual. ${ }^{7}$

Ketidakpastian adalah persoalan mendasar dalam semua aktivitas ekonomi. Bagaimanapun, suatu hasil yang tidak pasti diatur oleh sebab-sebab tertententu yang memungkinkan adanya suatu kejadian. Maka jika suatu agen yang mencari pendapatan yang tidak pasti, pengusaha perlu menerapkan tindakan yang mengendalikan berbagai kejadian untuk memperoleh pendapatan tersebut.

Faktor-faktor yang dapat mengendalikan kemungkinan suatu hasil yang tidak pasti diperlukan sebagai penyebab. Dalam tradisi Islam, ketidakpastian benar-benar dihubungkan dengan penyebabnya. Menghadapi suatu masalah dalam keputusan yang tidak pasti, pada umumnya orang berpikir untuk melakukan penyebab itu dan menyerahkan hasil akhirnya kepada kehendak

7 Shalah ash-Shawi \& Abdullah al-Mushlih, Fikih Ekonomi Keuangan Islam, (Jakarta:Darul Haq, 2011), hlm. 16 
Allah swt. Pendekatan kausalitas terhadap pengambilan keputusan inilah yang menunjukkan suatu perbedaan fundamental antara ekonomi Islam dengan ekonomi neo klasik (konvensional). ${ }^{8}$

Adapun beberapa tipe utama gharar yaitu sebagai berikut:

1. Gharar yang dikarenakan ketiadaan nilai-nilai penyeimbang yang dipertukarkan, atau ketiadaan kontrol para pihak atas materi pokok bahasan (objek) yang hendak dipertukarkan. Dengan istilah modern sistem konvensional, gharar tipe ini dikenal sebagai risiko penyelesaian (settlement risk) atau risiko pihak lawan (contra-party risk), yakni penjual.

2. Gharar yang dikarenakan ketidakcukupan atau ketidakakuratan informasi. Gharar tipe ini mungkin timbul dikarenakan tidak menyingkapnya informasi relevan tentang materi pokok bahasannya (barang). Materi pokok bahasan ini terdiri dari karaktersitik nilai kontra yang dipertukarkan, jenisnya, kuantitasnya, tanggal penyerahan mendatang, dan lain-lain. Alasan melarang gharar tipe ini adalah karena ada kemungkinan pemerdayaan dan penipuan di dalam kontrak semacam ini, dikarenakan kesengajaan merahasiakan informasi bernilai atau informasi relevan oleh salah satu pihak manapun perihal kontrak tersebut.

3. Gharar yang dikarenakan kompleksitas yang tidak semestinya ada di dalam kontrak, seperti menggabungkan dua penjualan di dalam satu atau dua atau lebih kontrak yang saling berkaitan. Contoh dua penjualan di dalam satu kontrak adalah ketika seseorang berkata kepada yang lain: "saya menjual kepadamu barang ini seharga RM100 secara tunai hari ini, dan RM110 harus dibayarkan dalam

${ }^{8}$ Muhammad, Manajemen Keuangan Syariah Analisis Fiqh \& Keuangan, (Yogyakarta: UPP STIM YKPN, 2014), hlm. 178 
satu tahun." Pembeli tersebut lalu berkata: "saya menerima" tanpa merinci dengan harga mana ia membeli barang tersebut. ${ }^{9}$

\section{E. Konsep Maysir dalam Lembaga Keuangan Syariah}

Perjudian atau maysir, yang dikenal juga sebagai qimar, didefenisikan sebagai segala aktivitas yang melibatkan pertaruhan, yang melaluinya pemenang akan mengambil seluruh taruhan dan pihak yang kalah akan kehilangan taruhannya. Perjudian berarti permainan peluang murni, yakni pihak manapun mungkin memperoleh keuntungan disertai kerugian pihak yang lain. ${ }^{10}$

Al-Qur'an secara eksplisit mengutuk dan melarang perjudian. Hal ini sesuai dengan firman Allah swt dalam surah al-Maidah ayat 90-91:

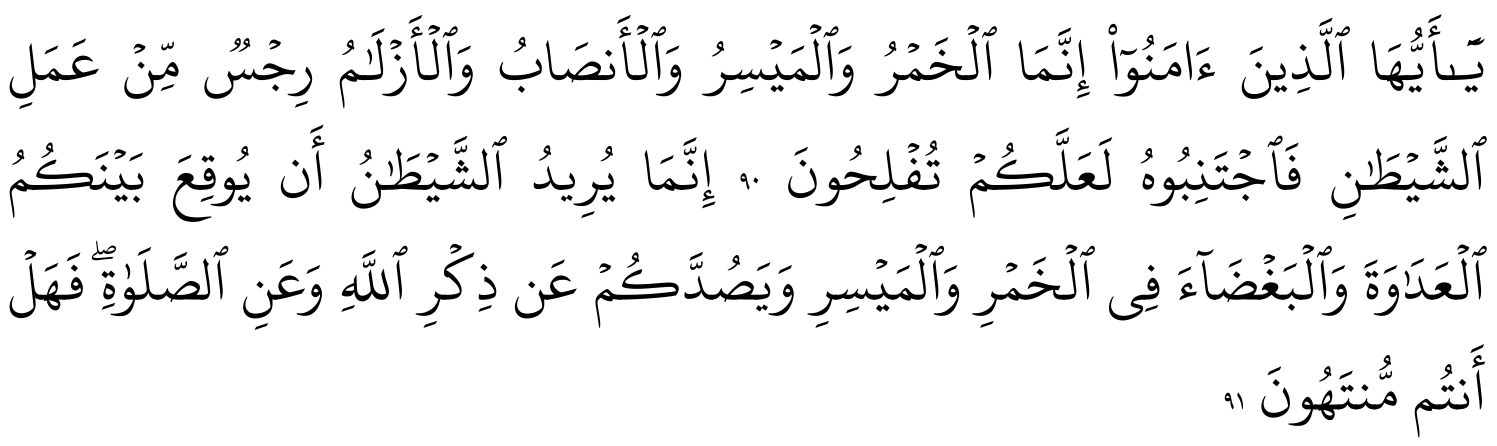

Hai orang-orang yang beriman, Sesungguhnya (meminum) khamar, berjudi, (berkorban untuk) berhala, mengundi nasib dengan panah, adalah Termasuk perbuatan syaitan. Maka jauhilah perbuatan-perbuatan itu agar kamu mendapat keberuntungan. Sesungguhnya syaitan itu bermaksud hendak menimbulkan permusuhan dan kebencian di antara kamu lantaran (meminum) khamar dan berjudi itu, dan menghalangi kamu dari mengingat Allah dan sembahyang; Maka berhentilah kamu (dari mengerjakan pekerjaan itu).

9 ISRA, Sistem Keuangan Islam; Prinsip \& Operasional, (Jakarta: Rajawali Press, 2015), hlm. 10 Ibid, hlm. 219 


\section{F. Konsep Pembiayaan dalam Lembaga Keuangan Syariah}

1. Pengertian Pembiayaan

Dalam masyarakat Indonesia, selain dikenal istilah utang piutang juga dikenal istilah kredit dalam perbankan konvensional dan istilah Pembiayaan dalam perbankan syariah. Utang piutang biasanya digunakan oleh masyarakat dalam konteks pemberian pinjaman pada pihak lain. Seseorang yang meminjamkan hartanya pada orang lain maka ia dapat disebut telah memberikan utang padanya. Sedangkan istilah kredit atau pembiayaan lebih banyak digunakan oleh masyarakat pada transaksi perbankan dan pembelian yang tidak dibayar secara tunai. Secara esensial, antara utang dan kredit atau pembiyaan tidak jauh beda dalam pemaknaannya di masyarakat.

Pembiayaan selalu berkaitan dengan aktivitas bisnis. untuk itu, sebelum kita masuk kepada masalah pengertian pembiayaan, perlu kita ketahui apa itu bisnis. Bisnis adalah aktivitas yang mengarah kepada peningkatan nilai tambah melalui proses penyerahan jasa, pedagangan atau pengolahan barang (produksi). dengan kata lain, bisnis merupakan aktivitas berupa pengembangan aktivitas ekonomi dalam bidang jasa, perdagangan dan industri guna mengoptimalkan nilai keuntungan. ${ }^{11}$

Pembiayaan atau financing ialah pendanaan yang diberikan oleh suatu pihak kepada pihak lain untuk mendukung untuk investasi yang telah direncanakan, baik dilakukan sendiri maupun lembaga. dengan kata lain, pembiayaan adalah pendanaan yang dikeluarkan untuk mendukung investasi yang telah direncanakan. ${ }^{12}$

\footnotetext{
hlm. 17

${ }^{11}$ Muhammad, Manajemen Pembiayaan bank Syariah, (Yogyakarta: UPP AMP KYPN, 2005), 12 Ibid
} 
Dalam UU Nomor 10 tahun 1998 disebutkan bahwa pembiayaan berdasarkan prinsip syariah yaitu penyediaan uang atau tagihan yang dipersamakan dengan itu berdasarkan persetujuan atau kesepakatan antara bank dengan pihak lain yang mewajibkan pihak yang dibiayai untuk mengembalikan uang atau tagihan tersebut setelah jangka waktu tertentu dengan imbalan atau bagi hasil. ${ }^{13}$

Istilah pembiayaan pada intinya berarti I believe, I Trust, 'saya percaya' atau 'saya menaruh kepercayaan'. Perkataan pembiayaan yang berarti (trust), berarti lembaga pembiayaan selaku shahibul mal menaruh kepercayaan kepada seseorang untuk melaksanakan amanah yang diberikan. Dana tersebut harus digunakan dengan benar, adil, dan harus disertai dengan ikatan dan syarat-syarat yang jelas dan saling menguntungkan bagi kedua belah pihak. ${ }^{14}$

Dalam kaitannya dengan pembiayaan pada perbankan Islam atau istilah teknisnya disebut sebagai aktiva produktif. Aktiva produktif adalah penanaman dana bank Islam baik dalam Rupiah maupun valuta asing dalam bentuk pembiayaan, piutang, qardh ${ }^{15}$, surat berharga Islam ${ }^{16}$, penempatan ${ }^{17}$, penyertaan modal ${ }^{18}$, penyertaan

13 UU RI Nomor 10 tahun 1998 tentang Perubahan atas UU Nomor 7 tahun 1992 tentang Perbankan

14 Veithzal Rivai \& Andria Permata Veithzal, Islamic Financial Management, (Jakarta: PT. RagaGrafindo Persada, 2008), hlm. 3

15 Al-qardh adalah suatu akad pinjaman (penyaluran dana) kepada nasabah dengan ketentuan bahwa nasabah wajib mengembalikan dana yang diterimanya kepada lembaga keuangan syariah (LKS) pada waktu yang telah disepakati oleh LKS dan nasabah., Z.Dunil, Kamus Istilah Perbankan Indonesia, (Jakarta: PT Gramedia, 2004), hlm. 314

${ }^{16}$ Surat berharga syariah adalah surat bukti berinvestasi berdasarkan prinsip syariah yang lazim diperdagangkan di pasar uang dan/atau pasar modal antara lain wesel, obligasi syariah, sertifikat reksadana syariah, dan surat berharga lainnya berdasarkan prinsip syariah. Ibid, hlm. 330

17 Penempatan (oleh bank syariah) adalah penanaman dana bank syariah pada bank syariah lainnya dan/atau bank perkreditan rakyat berdasarkan prinsip syariah antara lain dalam bentuk giro dan/atau tabungan wadiah, deposito berjangka dan/atau tabungan mudharabah, pembiayaan yang diberikan, sertifikat investasi mudharabah antarbank (IMA) dan/atau bentuk-bentuk penempatan lainnya berdasarkan prinsip syariah, Ibid, hlm. 326

18 Penyertaan modal (oleh bank syariah) adalah penanaman dana bank syariah dalam bentuk saham pada perusahaan yang bergerak dalam bidang keuangan syariah, termasuk penanaman dalam bentuk utang konversi (convertible bonds) dengan opsi saham (equity option) atau jenis transaksi tertentu 
modal sementara19, komitmen dan kontijensi pada rekening administrasi serta sertifikat wadiah. ${ }^{20}$

2. Prinsip-prinsip Pembiayaan

Pemberian pembiayaan konvensional meminjamkan uang kepada yang membutuhkan dan menganmbil bagian keuntungan berupa bunga dan provisi dengan cara membungakan uang yang dipinjam tersebut. Prinsip meniadakan transaksi semacam ini dan mengubahnya menjadi pembiayaan dengan tidak meminjamkan sejumlah uang pada custemer, tetapi membiayai proyek custemer. Dalam hal ini bank berfungsi sebagai intermediasi uang tanpa meminjamkan uang dan membungakan uang tersebut. Sebagai gantinya, pembiayaan usaha custemer tersebut dapat dilakukan dengan cara membelikan barang yang dibutuhkan custemer, lalu bank menjual kembali kepada custemer, atau dapat pula dengan cara mengikutsertakan modal dalam usaha custemer. $^{21}$

Lazimnya dalam bisnis prinsip pembiayaan, ada tiga skim dalam melakukan akad pada bank syariah, yaitu:

a. Prinsip bagi hasil

Fasilitas pembiayaan yang disediakan disini berupa uang tunai atau barang yang dinilai dengan uang. Jika dilihat dari sisi jumlah, dapat menyediakan sampai $100 \%$ dari modal yang diperlukan, ataupun dapat pula hanya sebagian saja berupa patungan antar bank dengan pengusaha (custemer), jika dilihat

berdasarkan prinsip syariah yang berakibat bank syariah memiliki atau akan memiliki saham pada perusahaan yang bergerak di bidang keuangan syariah. Ibid, hlm. 326

19 Penyertaan modal sementara (oleh bank syariah) adalah penyertaan modal bank syariah dalam perusahaan nasabah untuk mengatasi kegagalan pembiayaan dan/atau piutang (debt to equity swap) sebagaimana dimaksud dalam ketentuan bank Indonesia yang berlaku, termasuk dalam bentuk surat utang konversi (convertible bonds) dengan opsi saham (equity option) atau jenis transaksi tertentu yang berakibat bank syariah memiliki atau akan memiliki saham pada perusahaan nasabah, Ibid, hlm. 326

${ }^{20}$ Veithzal Rivai \& H. Arviyan Arifin, Islamic Banking: Sebuah Teori, Konsep, dan Aplikasi, (Jakarta: Bumi Akasara, 201), hlm. 681

21 Veithzal Rivai \& Andria Permata Veithzal, Islamic Financial..........., hlm. 42 
dari sisi bagi hasilnya, ada dua jenis bagi hasil (tergantung kesepakatan), yaitu revenue sharing atau profit sharing. Sedangkan dalam hal presentase bagi hasilnya dikenal dengan nisbah, yang dapat disepakati dengan custemer yang mendapat faslitas pembiayaan pada saat akad pembiayaan. Prinsip bagi hasil ini terdapat dalam produk-produk:

1) Mudaharabah

2) Musyarakah

3) Muzara'ah

b. Prinsip jual beli

Prinsip ini merupakan suatu sistem yang menerapkan tata cara jual beli, dimana bank akan membeli terlebih dahulu barang yang dibutuhkan atau mengangkat nasabah sebagai agen bank melakukan pembelian barang atas nama bank, kemudian bank menjual barang tersebut kepada nasabah dengan harga sejumlah harga beli ditambah keuntungan (margin/mark-up). ${ }^{22}$

Prinsip ini dilaksanakan karena adanya perpindahan kepemilikan barang atau benda. Tingkat keuntungan bank ditetapkan di muka dan menjadi bagian antar harga barang yang diperjualbelikan. Prinsip ini terdapat dalam produk:

1) Bai' al-Murabahah

2) Bai' al-muqayyadah

3) Bai' al-mutlaqah

4) Bai' As-salam

5) Bai' al-istishna

c. Prinsip sewa menyewa.

22 Muhammad (Ed), Bank Syariah: Analis Kekuatan, Kelemahan, Peluang dan Ancaman, (Yogyakarta: Ekonisi, 2006), hlm. 18 
Selain akad jual beli yang telah dijelaskan sebelumnya, ada pula akad sewa menyewa yang dilaksanakan dalam perbankan syariah. Prinsip ini terdiri dari dua jenis akad, yaitu:

1) akad ijarah,

2) akad ijarah muntabhia bit tamlik.

\section{G. Konsep Pengambilan Keuntungan}

Sistem keuangan dan perbankan islam merupakan bagian dari konsep yang lebih luas tentang ekonomi islam, dimana tujuannya sebagaimana dianjurkan oleh para ulama adalah memberlakukan sistem nilai dan etika islam ke dalam lingkungan ekonomi. Karena dasar etika inilah maka keuangan dan perbankan islam bagi kebanyakan muslim adalah bukan sekedar sistem transaksi komersial. Persepsi islam dalam transaksi finansial itu dipandang oleh kebanyakan kalangan muslim sebabagi kewajiban agama. Kemampuan lembaga keuangan islam menarik investor dengan sukses bukan hanya tergantung pada tingkat kemampuan lembaga itu menghasilkan keuntungan, tetapi juga pada persepsi bahwa lembaga tersebut secara sungguh-sungguh memperhatikan batas-batas yang digariskan oleh islam. ${ }^{23}$

Ekonomi Islam atau keuangan Islam merupakan suatu bagian yang penting, hal ini diperluas ke dalam beberapa peraturan dan dorongan. Peraturan (larangan) mengenai riba dan izin untuk melakukan perdagangan, menjadi bukti yang terdapat di dalam alqur'an. Sebagaimana Allah swt berfirman dalam surah al- Baqarah ayat 275:

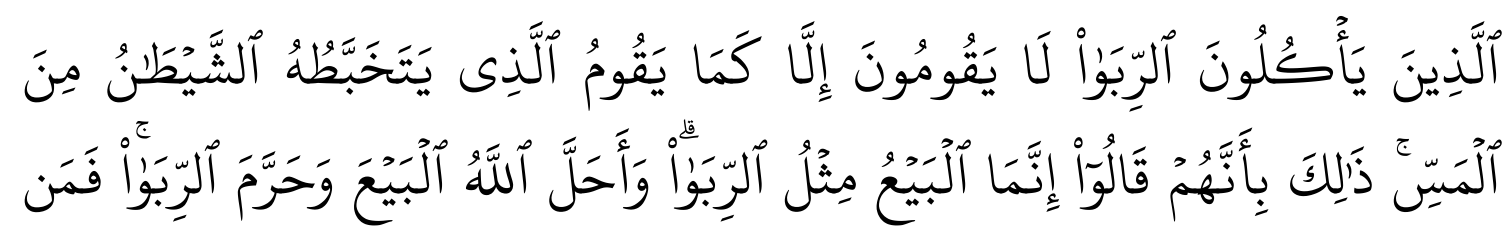

${ }^{23}$ Zainul Arifin, Dasar-dasar Manajemen Bank Syariah, (Jakarta: Pustaka Alvabet, 2006), hlm. 12 


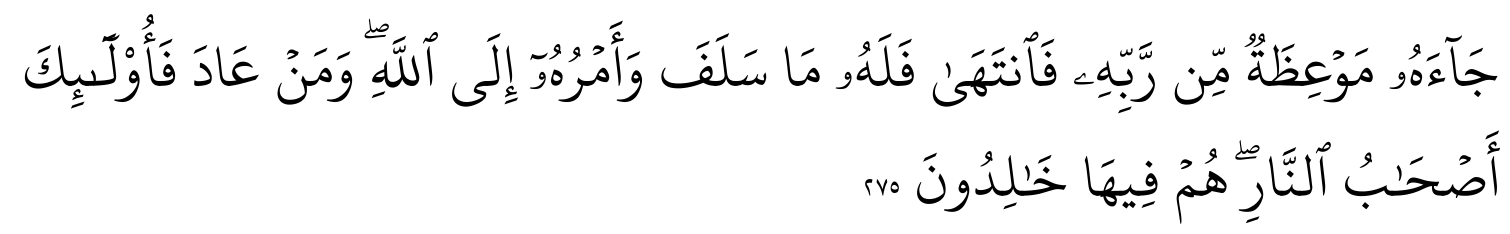

Orang-orang yang Makan (mengambil) riba tidak dapat berdiri melainkan seperti berdirinya orang yang kemasukan syaitan lantaran (tekanan) penyakit gila. Keadaan mereka yang demikian itu, adalah disebabkan mereka berkata (berpendapat), Sesungguhnya jual beli itu sama dengan riba, Padahal Allah telah menghalalkan jual beli dan mengharamkan riba. orang-orang yang telah sampai kepadanya larangan dari Tuhannya, lalu terus berhenti (dari mengambil riba), Maka baginya apa yang telah diambilnya dahulu (sebelum datang larangan); dan urusannya (terserah) kepada Allah. orang yang kembali (mengambil riba), Maka orang itu adalah penghuni-penghuni neraka; mereka kekal di dalamnya. ${ }^{24}$

Allah mengijinkan/menghalalkan memperoleh keuntungan, akan tetapi yang berasal dari perdagangan dan melarang riba. Mendorong aktivitas keuangan di dalam ekonomi Islam terhadap aset yang berasal dari bisnis dan transaksi. Hal ini menjelaskan bahwa seluruh transaksi keuangan harus menyajikan transaksi yang nyata atau penjualan atas barang, jasa sehingga meraih keuntungan. Sebagai imbalan Islam juga menetapkan standar moral atau perilaku yang hampir menjadi bagian dari kehidupan masyarakat.

Struktur keuangan Islam berputar disekitar larangan atas pinjaman (riba) dan legalitas suatu keuntungan. Riba pada dasarnya diartikan sebagai bunga, merupakan suatu penambahan yang dianggap sebagai premium dari debitur. Hal ini menyajikan tingkat pengembalian transaksi termasuk pertukaran uang untuk uang, atau akun atas penundaan pembayaran atas harga yang telah disepakati di dalam sales debts. Syariah Islam melarang ekonomi yang tidak seimbang, seluruh transaksi yang mengandung bunga sangatlah dilarang, utang kontrak tidak dapat dijual pada harga premium atau discount.

24 Departemen Agama RI, Al-Qur'an dan Terjemahan, (Surabaya: Mekar Surabaya, 2004), hlm. 
Dalam konteks keuangan Islam, pinjaman hanya berasal dari kegiatan moneter atau keuangan saja dimana keuangan Islam bertukar tangan dengan jaminan pengembalian penuh tanpa pengembalian apapun ke kreditor. Invsetasi menurut konteks Islam bukan merupakan kegiatan transaksi moneter atau keuangan yang murni, dimana kegiatan transfer dana merupakan kegiatan yang bersifat nyata. ${ }^{25}$

Semua keuntungan dari investasi atau pokok dari suatu bisnis tidaklah dilarang. Berdasarkan keseluruhan prinsip yang ditunjukkan oleh syariah, para cendikiawan telah mengidentifikasi beberapa metode yang menguntungkan dalam pemanfaatan daya yang berlebihan dengan tujuan meningkatkan nilainya. Keuntungan telah diakui sebagai "imbalan" atas modal dan Islam mengizinkan pemanfaatan sumber daya yang berlebih secara menguntungkan. Hasil keuntungan riil yang diperbolehkan syariah melambangkan kewirausahaan dan penciptaan kekayaan tambahan. Namun, bersamaan dengan hak atas keuntungan, tanggungjawab risiko atas kerugian bertumpu pada modalnya itu sendiri. Tidak boleh ada faktor lain yang dapat digunakan untuk menanggung beban kerugian atas modal. ${ }^{26}$

\section{H. Konsep Transparansi dan Keadilan}

1. Transparansi

Kegiatan usaha dalam kaca mata Islam memiliki kode etik yang bisa memelihara kejernihan aturan ilahi, jauh dari sikap serakah dan egoisme, sehingga membuat usaha tersebut sebagai mediator dalam membentuk masyarakat yang saling mengasihi satu sama yang lain. Bank islami dan institusi finansial dituntut untuk mengadopsi transparansi, disklosur, serta dokumentasi lebih jauh dibandingkan

${ }^{25}$ Veithzal Rivai dkk, Principle of Islamic Finance, dasar-dasar Keuangan Islam, (Yogyakarta: BPFE Yogyakarta, 2014), hlm. 91

26 Muhammad Ayub, Understanding Islamic Finance; A-Z Keuangan Syariah, (Jakarta, PT. Gramedia Pustaka Utama, 2009), hlm. 121 
bank konvensional. Kurangnya transparansi dalam transaksi murabahah, dimana bank islami dituntut untuk menyediakan semua detail dari biaya/harga dan cara pembayaran, bisa menjadikan transaksinya tidak sesuai dengan ajaran syariah. Kitab suci al-qur'an memerintahkan kita menulis dan menjadi saksi dalam semua transaksi yang melibatkan kredit dalam bentuk apa pun. Hal serupa juga diungkapkan oleh Nabi Muhammad saw; bahwa ia mendukung disklosur atas semua karakteristik barang yang diperdagangkan dan lingkungan yang kompetitif tempat orang-orangnya mendapatkan informasi memadai mengenai barang dan harganya di pasar. ${ }^{27}$

2. Keadilan

Allah adalah pencipta segala sesuatu. Dan salah satu sifatnya adalah adil. Dia tidak menbeda-bedakan perlakuan terhadap mahkluknya secara zalim. Manusia sebagai khalifah dimuka bumi ini harus memelihara hukum Allah dimuka bumi, dan menjamin bahwa pemakaian segala sumber daya diarahkan untuk kesejahteraan manusia, supaya semua mendapat manfaat daripadanya secara adil.

Dalam al-Qur'an Allah swt memerintahkan manusia untuk berbuat adil, serti dalam surah al-Maidah ayat 5:

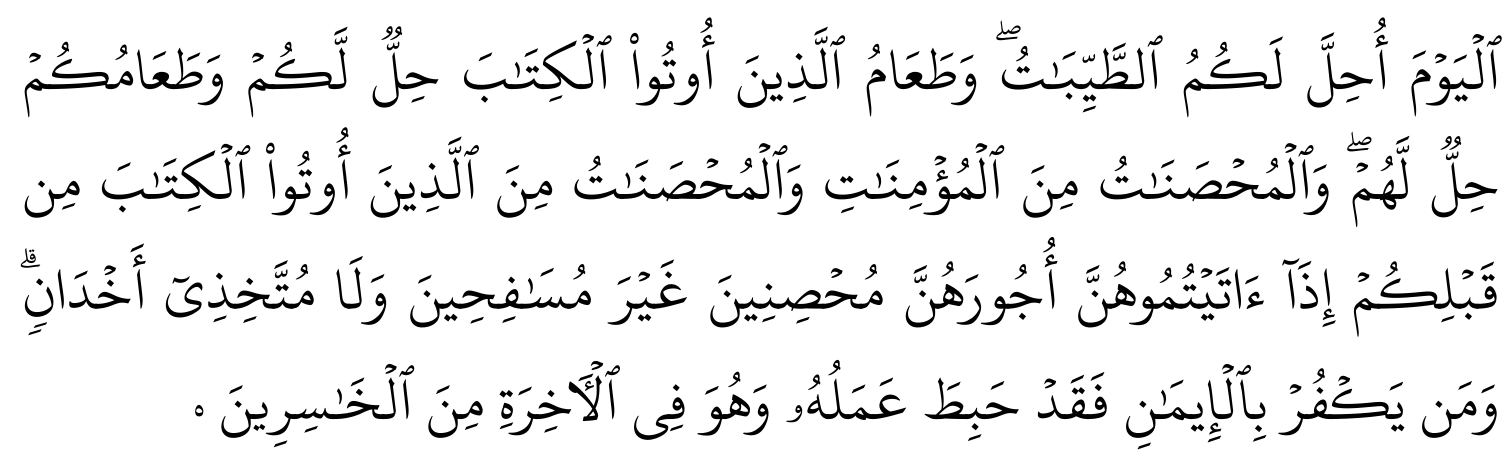

Hai orang-orang yang beriman hendaklah kamu Jadi orang-orang yang selalu menegakkan (kebenaran) karena Allah, menjadi saksi dengan adil. dan janganlah sekali-kali kebencianmu terhadap sesuatu kaum, mendorong kamu untuk Berlaku tidak adil. Berlaku adillah, karena adil itu lebih dekat kepada

27 Ibid, hlm. 130 
takwa. dan bertakwalah kepada Allah, Sesungguhnya Allah Maha mengetahui apa yang kamu kerjakan.

Dan surah al-An'am ayat 152:

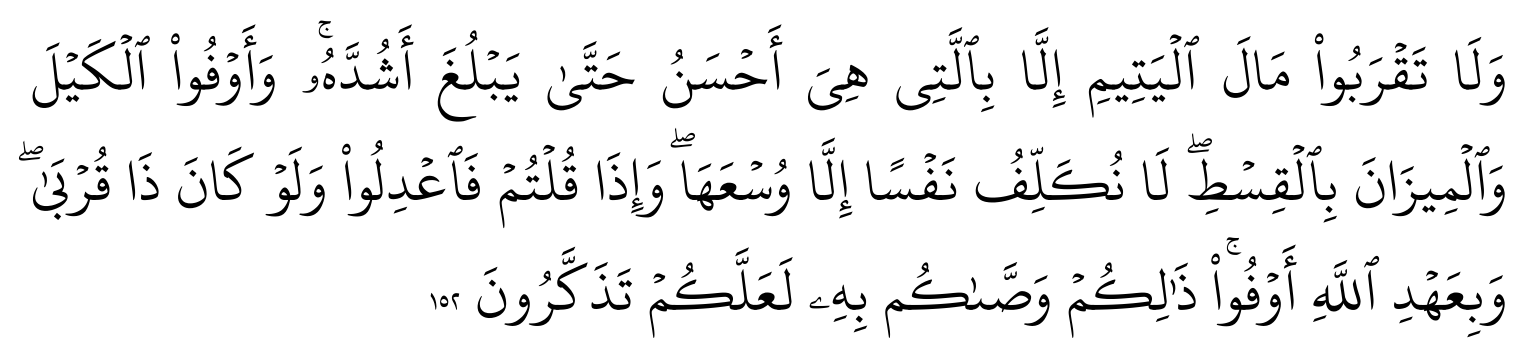

Dan janganlah kamu dekati harta anak yatim, kecuali dengan cara yang lebih bermanfaat, hingga sampai ia dewasa. dan sempurnakanlah takaran dan timbangan dengan adil. Kami tidak memikulkan beban kepada sesorang melainkan sekedar kesanggupannya. dan apabila kamu berkata, Maka hendaklah kamu Berlaku adil, Kendatipun ia adalah kerabat(mu), dan penuhilah janji Allah. yang demikian itu diperintahkan Allah kepadamu agar kamu ingat.

Dalam Islam adil didefenisikan sebagai "tidak menzalimi dan tidak dizalimi". Implikasi dari nilai ekonomi ini adalah bahwa pelaku ekonomi tidak dibolehkan untuk mengejar keuntungan pribadi bila hal itu merugikan orang lain atau merusak alam. Tanpa keadilan manusia akan terkelompok-kelompok dalam berbagai golongan. Golongan yang satu akan menzalimi golongan yang lain, sehingga terjadi eksploitasi manusia atas manusia. ${ }^{28}$

Keadilan dalam Islam memiliki implikasi sebagai berikut:

a. Keadilan sosial

Islam menganggap umat manusia sebagai suatu keluarga. Karenanya semua anggota keluarga ini mempunyai derajat yang sama dihadapan Allah. Hukum allah tidak membedakan yang kaya dan yang miskin, demikian juga tidak membedakan yang hitan dan yang putih. Secara sosial, nilai yang membedakan satu

${ }^{28}$ Adiwarman A Karim, Ekonomi Mikro Islami, (Jakarta: PT. RajaGrafindo Persada, 2007), hlm. 
dengan yang lain adalah ketaqwaan, ketulusan hati, kemampuan, dan pelayanan pada kemanusiaan. Sifat-sifat tersebut merupakan cerminan dari ketaqwaan seseorang. Perlakuan adil akan membawa kesejahteraan karena kesejahteraan sangat bergantung pada diberlakukannya hukum Allah dan dihilangkan ketidakadilan.

b. Keadilan ekonomi

Konsep persaudaaran dan perlakuan yang sama bagi setiap individu dalam masyarakat di dihadapan hukum harus diimbangi oleh keadilan ekonomi. Tanpa pengimbangan tersebut, keadilan sosial kehilangan makna. Dengan keadilan ekonomi, setiap individu akan mendapatkan haknya sesuai dengan kontribusi masing-msing kepada masyarakat. Setiap individupun harus terbebaskan dari eksploitasi individu lainnya. Hal ini sesuai dengan firman Allah swt dalam surah asy-Syu'araa ayat 183:

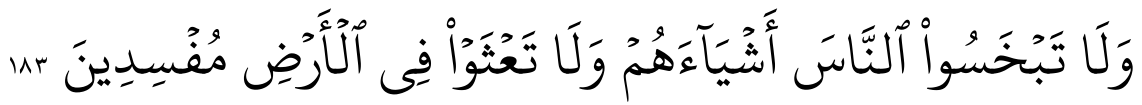

Dan janganlah kamu merugikan manusia pada hak-haknya dan janganlah kamu merajalela di muka bumi dengan membuat kerusakan;29

Konsep keadilan ekonomi dalam islam mengharuskan setiap orang mendapatkan haknya dan tidak mengambil hak atau bagian orang lain. Peringatan akan ketidakadilan dan eksploitasi ini dimaksudkan untuk melindungi hak-hak individu dalam masyarakat, juga untuk meningkatkan kesejahteraan umum sebagai tujuan utama islam. ${ }^{30}$

Salah atu sumbangan terbesar Islam kepada umat manusia adalah prinsip keadilan dan pelaksanaannya dalam setiap aspek

${ }^{29}$ Departemen Agama RI, Al-Qur'an ........., hlm. 526

30 Muhammad Syafi'i Antonio, Bank Syariah dari Teori ke Praktik, (Jakarta: Gema Insani, 2001), hlm. 15 
kehidupan manusia, islam memberikan suatu aturan yang dapat dilaksanakan sebagai pengganti amalan-amalan tradisional yang bertentangan. Setiap anggota masyarakat didorong untuk memperbaiki kehidupan material masyarakat disamping berusaha untuk memperbaiki kehidupan rohani dan mengingatkan bahwa setiap benda di dunia ini adalah untuk diambil manfaatnya. Tetapi secara bersamaan Islam mendidik mereka bertanggungjawab bukan saja kepada istri dan keluarga, tetapi juga saudara-saudaranya yang miskin dan melarat, negara dan akhirnya seluruh makhluk. Setelah mendapatkan manfaat dari harta kekayaannya masing-masing, sudah selayaknya memberikan faedah yang sama kepada masyarakat yang lain. ${ }^{31}$

Oleh karena itu, dengan mengubah sifat hanya memetingkan diri sendiri manusia kepada sifat yang sebaliknya (tidak hanya mementingkan diri sendiri), dan menyalurkan atau memberi jalan keluar tanpa suatu tekanan, Islam berhasil memberikan suatu penyelesaikan yang praktis kepada masalah ekonomi modern. Semua orang didorong untuk bekerja bersamasama dalam menyusun suatu sistem ekonomi yang berdasarkan prinsip persamaan dan keadilan kepada semua orang dan yang tidak hanya tertuju kepada individu atau pihak tertentu saja dalam masyarakat. Dalam sistem ini, setiap individu menjadi unit yang berguna kepada semua pihak, dengan bekerja untuk dirinya sendiri dan masyarakat keseluruhan.

31 Afzalur Rahman, Doktrin Ekonomi Islam Jilid 1, (Yogyakarta: PT. Dana Bhakti wakaf, 1995), hlm. 74 
Rahmat Ilyas

\section{Kesimpulan}

Filosofi sistem keuangan "bebas bunga" (larangan riba) tidak hanya melihat interaksi antara faktor produksi dan prilaku ekonomi seperti yang dikenal pada sistem keuangan konvensional, melainkan juga harus menyeimbankan berbagai unsur etika, moral, sosial dan dimensi keagamaan untuk meningkatkan pemerataan dan keadilan menuju masyarakat yang sejahtera secara menyeluruh.

Jual beli gharar adalah jual beli yang mengandung unsur-unsur penipuan, baik karena ketidakjelasan dalam objek jual beli atau ketidakpastian dalam cara pelaksanaannya. Hukum jual beli ini adalah haram. Alasan haramnya adalah tidak pasti dalam objek, baik barang atau uang atau cara transaksinya itu sendiri. Karena larangan dalam hal ini langsung menyentuh esensi jual belinya, maka disamping haram hukumnya transaksi itu tidak sah

Perjudian atau maysir, yang dikenal juga sebagai qimar, didefenisikan sebagai segala aktivitas yang melibatkan pertaruhan, yang melaluinya pemenang akan mengambil seluruh taruhan dan pihak yang kalah akan kehilangan taruhannya. Perjudian berarti permainan peluang murni, yakni pihak manapun mungkin memperoleh keuntungan disertai kerugian pihak yang lain. Al-Qur'an secara eksplisit mengutuk dan melarang perjudian. Hal ini sesuai dengan firman Allah swt dalam surah al-Maidah ayat 90-91. 


\section{DAFTAR PUSTAKA}

Adiwarman A karim, Ekonomi Islam Suatu Kajian Kontemporer, (Jakarta, Gema Insani Press, 2001)

Persada, 2007)

Afzalur Rahman, Doktrin Ekonomi Islam Jilid 1, (Yogyakarta, PT. Dana Bhakti wakaf, 1995)

Amir Syarifuddin, Garis-garis Besar Fiqh, (Jakarta, Kencana, 2010)

Departemen Agama RI, Al-Qur'an dan Terjemahan, (Surabaya, Mekar Surabaya, 2004)

ISRA, Sistem Keuangan Islam; Prinsip E Operasional, (Jakarta, Rajawali Press, 2015)

Mervyn K \& Latifa M. Algaoud, Perbankan Syariah: Prinsip, Praktik dan Prospek, (Jakarta: PT. Serambil Ilmu Semesta, 2001)

Lukman Hakim, Prinsip-prinsip Ekonomi Islam, (Jakarta, Erlangga, 2012), hlm. 2

Muhammad, Manajemen Keuangan Syariah Analisis Fiqh \& Keuangan, (Yogyakarta, UPP STIM YKPN, 2014)

, Manajemen Pembiayaan bank Syariah, (Yogyakarta, UPP AMP KYPN, 2005)

Manajemen Keuangan Syariah; analisis Figh $\mathcal{E}$ Keuangan, (Yogyakarta:UPP STIM YKPN, 2014)

Muhammad (Ed), Bank Syariah: Analis Kekuatan, Kelemahan, Peluang dan Ancaman, (Yogyakarta, Ekonisi, 2006)

Muhammad Ayub, Understanding Islamic Finance; A-Z Keuangan Syariah, (Jakarta, PT. Gramedia Pustaka Utama, 2009)

Muhammad Syafi'i Antonio, Bank Syariah dari Teori ke Praktik, (Jakarta, Gema Insani, 2001)

Shalah ash-Shawi \& Abdullah al-Mushlih, Fikih Ekonomi Keuangan Islam, (Jakarta, Darul Haq, 2011) 
Rahmat Ilyas

UU RI Nomor 10 tahun 1998 tentang Perubahan atas UU Nomor 7 tahun 1992 tentang Perbankan

Veithzal Rivai \& Andria Permata Veithzal, Islamic Financial Management, (Jakarta, PT. RagaGrafindo Persada, 2008)

Veithzal Rivai \& H. Arviyan Arifin, Islamic Banking: Sebuah Teori, Konsep, dan Aplikasi, (Jakarta, Bumi Akasara, 201)

Veithzal Rivai dkk, Principle of Islamic Finance, dasar-dasar Keuangan Islam, (Yogyakarta, BPFE Yogyakarta, 2014)

Zainul Arifin, Dasar-dasar Manajemen Bank Syariah, (Jakarta, Pustaka Alvabet, 2006)

Z. Dunil, Kamus Istilah Perbankan Indonesia, (Jakarta, PT Gramedia, 2004) 